\title{
Light Availability and Salt Stress on Hazel Sterculia Seedlings
}

\author{
Breno Leonan de Carvalho Lima ${ }^{1}$ (D), Claudivan Feitosa de Lacerda ${ }^{2}$ (D), \\ Miguel Ferreira Neto ${ }^{3}$ (D), David de Holanda Campelo² (D), José Adriano da Silva² (D), \\ Pedro Francisco Sanguino Ortiz ${ }^{1}$ (D), Antonio Marcos Esmeraldo Bezerra ${ }^{2}$ \\ ${ }^{1}$ Universidade Federal Rural de Pernambuco - UFRPE, Recife/PE, Brasil \\ ${ }^{2}$ Universidade Federal do Ceará - UFC, Fortaleza/CE, Brasil \\ ${ }^{3}$ Universidade Federal Rural do Semi-Árido - UFERSA, Mossoró/RN, Brasil
}

\begin{abstract}
The objective of this study was to evaluate the effect of light availability and salt stress on the growth and quality of hazel sterculia seedlings. The experiment was conducted with two light conditions - full sun (L1), and 50\% shading (L2) - and five salinity levels in the irrigation water - 1.0 (S1), 2.2 (S2), 3.2 (S3), 4.2 (S4), and 5.1 (S5) dS $\mathrm{m}^{-1}$. The environment with $50 \%$ shading was the most suitable to produce hazel sterculia seedlings, even under high salinity $\left(5.1 \mathrm{dS} \mathrm{m}^{-1}\right)$. Increasing salinity negatively affects the growth and quality of hazel sterculia seedlings. Therefore, controlling sunlight availability and irrigation water saline conditions increases rooting potential and seedling survival in the field.
\end{abstract}

Keywords: Sterculia foetida L., growth, shading, salinity. 


\section{INTRODUCTION}

Soil salinization is one of the problems that affect agriculture in arid and semi-arid regions of northeastern Brazil. It occurs due to the poor quality water used for irrigation and excessive use of fertilizers, turning agricultural lands into degraded lands over time, and leading to desertification. Degraded land can be rehabilitated through reforestation (Dutra et al., 2012a; Dutra et al., 2015; Cavalcante et al., 2016). According to Feikema \& Baker (2011), reforesting areas with native species that have deep roots is one of the best alternatives to reduce the problems and effects of salinity in areas deforested for agriculture.

Regarding the landscaping of public areas and landscape recovery, seedlings of exotic trees can be a viable alternative for the reforestation of parks, bare-soil areas, and public roads (Dutta et al., 2016). Holanda et al. (2007) point out the importance of soil protection and coverage to reduce problems related to slopes collapsing and erosion in general.

In Brazil, hazel sterculia (Sterculia foetida L.) is an ornamental tree that can reach heights of 10 to $20 \mathrm{~m}$. According to Lorenzi (1998) this tree species is recommended for planting in squares and parks, and for recovery of degraded areas. Seedling production for this species in nurseries and environments with different light availability have been studied to understand the requirements of this plant species (Câmara \& Endres, 2008; Pinto et al., 2016). For example, the factors that affect the initial development of seedlings of forest species during the nursery phase must be determined to better manage these plants and obtain well-formed and vigorous plants that have greater probability of success following field transplantation.

Many studies assess the initial growth and response of seedlings to abiotic factors; however, few studies consider the seedling quality indexes, particularly in the Sterculia foetida species. In this context, the objective of the present study was to evaluate the effect of irrigation with saline water on the quality of chicha seedlings grown in two environments with different light availability.

\section{MATERIAL AND METHODS}

The experiment was carried out in September to November 2012, in the Center for Teaching and Research in Urban Agriculture (NEPAU) of the Federal
University of Ceará (UFC), Pici campus, Fortaleza CE, Brazil ( $\left.3^{\circ} 44^{\prime} 16^{\prime \prime} S, 38^{\circ} 34^{\prime} 22^{\prime \prime} \mathrm{W}\right)$. The predominant climate in the region is Aw', tropical rainy, with rainy seasons in summer and autumn, according to the Köppen climate classification. The region had annual average precipitation of $1500 \mathrm{~mm}$, evapotranspiration potential of $1700 \mathrm{~mm}$, average annual temperature of $27^{\circ} \mathrm{C}$, and relative air humidity of $80 \%$, according to the Pici campus weather station.

Hazel sterculia seeds were obtained in July 2012 from dry fruits around adult plants at full fruiting stage, in Macaíba RN, Brazil. The seeds were sun-dried for 48 hours, placed in a plastic bag, and stored under refrigeration $\left(\sim 10^{\circ} \mathrm{C}\right)$. The seeds were mechanically scarified as described by Silva et al. (2012) and sown in August 2012 in 72-cell plastic trays. A sandy loam texture soil, previously sieved in a 2-mm mesh sieve, and an organic compost - plant residues and manure - were used as substrate, at a volume ratio of 3:1, respectively. Irrigation was performed daily in the morning at 9:00 a.m.

Seedling emergence occurred nine days after sowing. 23 days after sowing, the seedlings presented a pair of well-defined leaves, with the second pair of leaves emerging, and average height of $9 \mathrm{~cm}$. The seedlings were transplanted to $8-\mathrm{dm}^{3}$ pots filled with the substrate at a volume ratio of 2:1 (soil:compost). The soil used was classified as Neossolo Fluvico (Entisol) by the Embrapa (2013). Soil samples from the 0.0-0.2 m layer were collected in the UFC's Vale do Curu experimental farm, in Pentecoste CE, Brazil. The soil physical and chemical characteristics were: sand $=678.8 \mathrm{~g} \mathrm{~kg}^{-1}$; silt $=239.8 \mathrm{~g} \mathrm{~kg}^{-1} ;$ clay $=81.4 \mathrm{~g} \mathrm{~kg}^{-1} ; \mathrm{pH}$ in water $=5.34$; organic carbon $=4.00 \mathrm{~g} \mathrm{~kg}^{-1} ;$ organic matter $=6.88 \mathrm{~g} \mathrm{~kg}^{-1}$; available $\mathrm{P}=0.12 \mathrm{mg} \mathrm{kg}^{-1} ; \mathrm{Ca}^{2+}=1.20 \mathrm{cmol}_{\mathrm{c}} \mathrm{kg}^{-1}$; $\mathrm{Mg}^{2+}=2.00 \mathrm{cmol} \mathrm{kg}_{c}^{-1} ; \mathrm{K}^{+}=0.30 \mathrm{cmol}_{c} \mathrm{~kg}^{-1} ; \mathrm{Na}^{+}=0.41 \mathrm{cmol}_{\mathrm{c}} \mathrm{kg}^{-1} ;$ $\mathrm{H}+\mathrm{Al}=4.40 \mathrm{cmol}_{c} \mathrm{~kg}^{-1}$; sum of bases $=3.91 \mathrm{cmol}_{c} \mathrm{~kg}^{-1}$; cation exchange capacity $=8.31 \mathrm{cmol}_{c} \mathrm{~kg}^{-1}$; base saturation $=47 \%$.

A 2-cm layer of crushed stones was placed in the lower part of the pots before filling them with the substrate to facilitate water drainage. After transplanting the seedlings to the pots, they went through a period of acclimatization in a greenhouse for 5 days. Subsequently, the pots were placed in a permanent location for treatment (28 days after sowing). Fertilization was carried out 18 days after the application of the treatments (DAT), following the recommendations of Gonçalves (1995). 
The treatments consisted of subjecting the seedling to two light conditions - full sun (L1), and 50\% shading (L2) - and five salinity levels in the irrigation water - 1.0 (Control) (S1), 2.2 (S2), 3.2 (S3), 4.2 (S4), and 5.1 (S5) $\mathrm{dS} \mathrm{m} \mathrm{m}^{-1}$. The experiment was conducted in a completely randomized design, using a split-plot arrangement, with three replications - pots containing a plant. The plots consisted of light availability conditions and the subplots consisted of irrigation water salinity levels.

The salt solution was prepared with the addition of sodium chloride $(\mathrm{NaCl})$ and calcium chloride $\left(\mathrm{CaCl}_{2} \cdot 2 \mathrm{H}_{2} \mathrm{O}\right)$ to water with electrical conductivity of $1.0 \mathrm{dS} \mathrm{m}^{-1}$, at rate of 7:3 $\mathrm{Na}: \mathrm{Ca}$, according to the EC of the water of the treatments $\left(\right.$ mmolc $\left.\mathrm{L}^{-1}=\mathrm{EC} \times 10\right)$, as explained by Rhoades et al. (2000). The EC were measured using a portable digital conductivity meter (EUTECH Instruments brand, model ECTestr high). Irrigation was performed manually once a day at 5:00 p.m. until substrate saturation was achieved, and concluded when the water began to drain through the base of the vessels.

Plant growth was evaluated at the end of experiment (56 DAT) by measuring the plant height $(\mathrm{PH})$ using a ruler, stem base diameter (SBD) using a digital caliper, number of leaves (NL) by manual counting, leaf area (LA) using an area meter (LI-3100, Li-Cor, Inc. Lincoln, NE, USA), and root (RDW), shoot (SDW), and total (TDW $=\mathrm{RDW}+\mathrm{SDW}$ ) dry weights, using a digital balance $(+0.1 \mathrm{~g})$. The $\mathrm{PH}$ to $\mathrm{SBD}$ and $\mathrm{PH}$ to SDW ratios, and the Dickson quality index
$(\mathrm{DQI}=\mathrm{TDW} /[(\mathrm{PH} / \mathrm{SBD})+(\mathrm{SDW} / \mathrm{RDW})]$ were calculated according to Dickson et al. (1960).

The data were subjected to analysis of variance $(p<0.05)$ using the Sisvar software (Ferreira, 2011). The Tukey test was used to compare the means in the light availability analysis. The effect of salinity was analyzed by regression and the data was fitted to the model that best describes the biological phenomenon.

\section{RESULTS AND DISCUSSION}

The analysis of variance indicated an interaction between light availability (L) and irrigation water salinity level (S) for the variable plant height $(\mathrm{PH})$. Individually, the factors affected the other morphological variables (NL, SBD, LA, SDW, RDW and TDW). Plants in the environment with $50 \%$ shading (L2) presented the best results (Table 1 ).

The interaction L x S for plant height $(\mathrm{PH})$ presented a decreasing linear model for seedlings in $\mathrm{L} 2$. The relative decrease in this variable from S5 to S1 was 36\% (Figure 1A). The salinity levels had no effects on $\mathrm{PH}$ in the environment with full sun (L1). The salinity level negatively affected the NL, SBD, and LA (Figures 1B, 1C, and 1D, respectively), decreasing their means by 31,21 , and $54 \%$ respectively, from S5 to S1.

The evapotranspiration decreased under lower solar irradiance; consequently, the plants absorbed less

Table 1. Analysis of variance for the effect of light availability (L) and irrigation water salinity level (S) on the initial growth of Sterculia foetida L. seedlings at 56 days after application of the treatments.

\begin{tabular}{|c|c|c|c|c|c|c|c|c|}
\hline \multirow{2}{*}{$\begin{array}{l}\text { Source of } \\
\text { Variation }\end{array}$} & \multirow{2}{*}{ DF } & \multicolumn{7}{|c|}{ Mean square } \\
\hline & & NL & PH & SBD & LA & SDW & RDW & TDW \\
\hline $\mathrm{L}$ & 1 & $100.83^{* *}$ & $384.49^{* *}$ & $33.20^{* *}$ & $1771217.29^{* *}$ & $121.38^{\star *}$ & $28.22^{* *}$ & $266.63^{\star *}$ \\
\hline Residue (a) & 4 & 2.93 & 9.33 & 1.54 & 9158.89 & 0.83 & 0.49 & 2.05 \\
\hline S & 4 & $18.37^{* *}$ & $33.38^{* *}$ & $4.74^{*}$ & $210863.11^{\star *}$ & $20.74^{* *}$ & $4.42^{\star *}$ & $43.74^{* *}$ \\
\hline $\mathrm{L} \times \mathrm{S}$ & 4 & $1.50^{\text {ns }}$ & $22.56^{* *}$ & $0.94^{\mathrm{ns}}$ & $15673.51^{\mathrm{ns}}$ & $1.43^{\mathrm{ns}}$ & $0.83^{\mathrm{ns}}$ & $3.86^{\mathrm{ns}}$ \\
\hline Residue (b) & 16 & 3.18 & 3.96 & 1.22 & 17834.53 & 1.31 & 0.92 & 4.08 \\
\hline $\mathrm{CV}_{\mathrm{a}}(\%)$ & & 14.23 & 16.96 & 14.18 & 15.27 & 16.80 & 24.61 & 17.26 \\
\hline \multirow{3}{*}{$\mathrm{CV}_{\mathrm{b}}(\%)$} & & 14.83 & 11.04 & 12.64 & 21.31 & 21.13 & 33.55 & 24.36 \\
\hline & & \multicolumn{7}{|c|}{ Means } \\
\hline & & units & $\mathbf{c m}$ & $\mathbf{m m}$ & $\mathrm{cm}^{2}$ & \multicolumn{3}{|c|}{---------- g plant ${ }^{-1}$---------- } \\
\hline Full sun (L1) & & $10.20 \mathrm{~b}$ & - & $7.70 \mathrm{~b}$ & $383.68 \mathrm{~b}$ & $3.42 \mathrm{~b}$ & $1.89 \mathrm{~b}$ & $5.31 \mathrm{~b}$ \\
\hline $50 \%$ Shading (L2) & & $13.87 \mathrm{a}$ & - & $9.80 \mathrm{a}$ & $869.65 \mathrm{a}$ & $7.44 \mathrm{a}$ & $3.83 \mathrm{a}$ & $11.27 \mathrm{a}$ \\
\hline
\end{tabular}

${ }^{* *}=$ significant at $1 \%$ probability by the $\mathrm{F}$ test; ${ }^{*}=$ significant at $5 \%$ probability by the $\mathrm{F}$ test. ${ }^{\mathrm{ns}}=$ not significant; DF $=$ degrees of freedom; $\mathrm{CV}=$ coefficient of variation; $\mathrm{NL}=$ number of leaves; $\mathrm{PH}=$ plant height; $\mathrm{SBD}=$ stem base diameter; $\mathrm{LA}=$ leaf area; SDW = shoot dry weight; RDW = root dry weight; and TDW = total dry weight. 
(A)

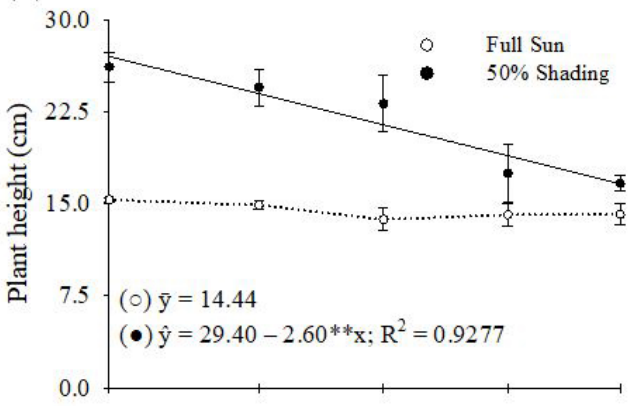

(C)

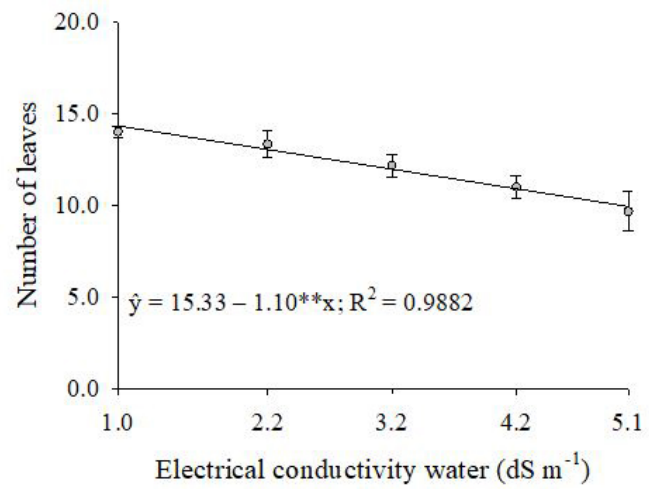

(B)

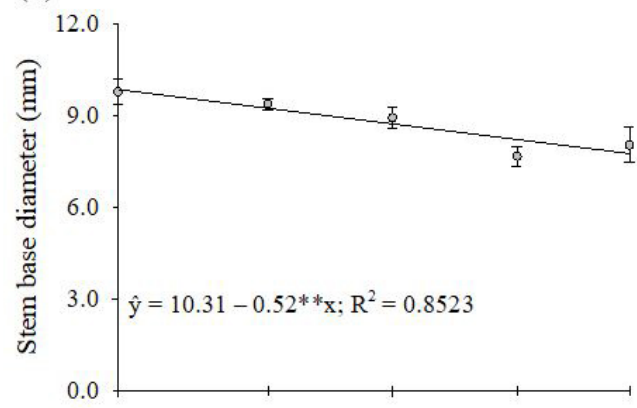

(D)

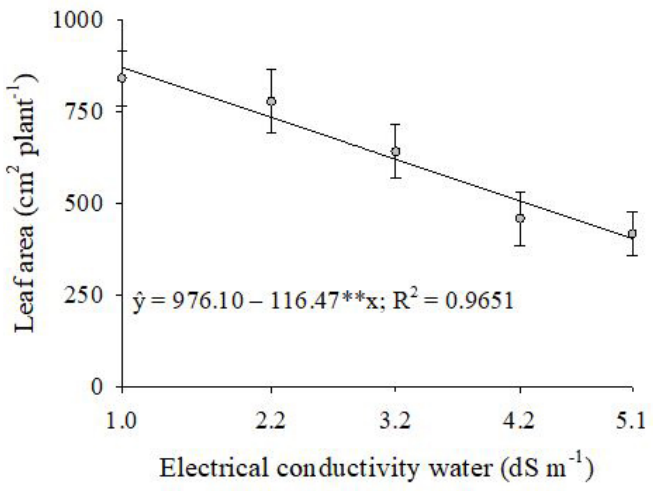

Vertical bars indicate the standard error.

Figure 1. Plant height (A), stem base diameter (B), number of leaves (C) and leaf area (D) of Sterculia foetida seedlings irrigated with saline water in environments with full sun, and 50\% shading at 56 days after application of the treatments. Fortaleza CE, Brazil, 2012.

water. Given this, the seedlings had less salt stress in L2 due to the lower accumulation of salt in the pots, as shown by the highest $\mathrm{PH}$ of seedlings in L2.

Câmara \& Endres (2008) found higher PH of Sterculia foetida under conditions of 70 and 50\% shading when compared with full sun; these authors attributed this to the shading. However, in the present study, the hazel sterculia seedlings in L2 had higher $\mathrm{PH}$, compared to those in L1, even under high stress conditions (S5).

The seedlings in L2 showed higher NL, SBD, LA, SDW, RDW and TDW means when compared to those in L1. Similarly, Câmara \& Endres (2008) found higher SBD, and better vegetative and root system development in Mimosa caesalpiniaefolia and Sterculia foetida seedlings grown under 50\% shading.

Heliophilous species grow in shaded environments followed by full sun, in natural forests, i.e., the young plants grown under shady conditions and develop in full sun as they mature. Therefore, these are the most favorable conditions for the development of seedlings of these species (Felfili et al., 1999).

Lima et al. (2008) found best growth and development of Caesalpinia ferrea grown under full sun conditions. However, Câmara \& Endres (2008) found less accumulated dry matter in Mimosa caesalpiniifolia and Sterculia foetida plants under full sun conditions. Dias-Filho (1997) assessed the response of Solanum crinitum to two light conditions and found that this species underwent morphological and physiological adjustments to compensate for the loss of photoassimilates in low light conditions, maintaining a satisfactory growth.

The accumulation of dry matter in the hazel sterculia seedlings was negatively affected by the salinity levels, presenting higher relative losses compared to the NL, SBD, and LA, with reductions of 60,53 and $58 \%$ for SDW, RDW and TDW respectively, at 56 DAT (Figure 2).

Mendonça et al. (2007) evaluated biometric characteristics of Eucalyptus spp. plants under salt stress conditions and observed growth reduction in 
the species E. camaldulensis, E. pellita and E. robusta in response to increasing salinity. Freire et al. (2010) evaluated the effect of soil salinity on the initial growth of Azadirachta indica and Melia azedarach and found a reduced height and dry matter accumulation in both species with increasing salinity. According to these authors, several factors contribute to reducing plant growth under salt stress, such as decreased water absorption, and reduction in photosynthetic rate and ion toxicity-especially $\mathrm{Na}^{+}$and $\mathrm{Cl}^{-}$.

The relative reduction in dry weight showed that the hazel sterculia seedlings are moderately sensitive to the salinity level of $5.1 \mathrm{dS} \mathrm{m}^{-1}$ (S5), according to the salinity tolerance classification proposed by Fageria et al.

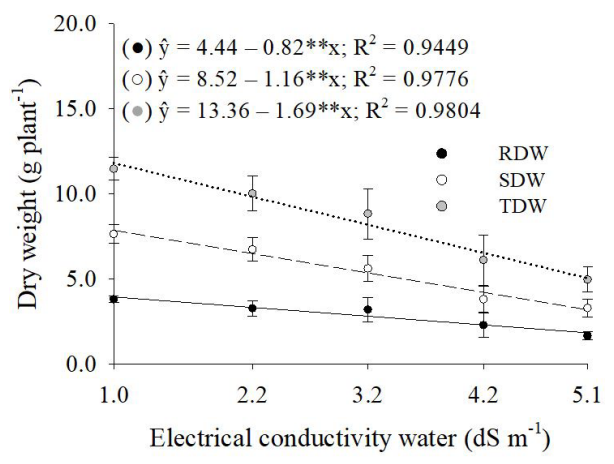

Vertical bars indicate the standard error.

Figure 2. Root $(\bullet)$, shoot $(\circ)$ and total $(\bullet)$ dry weights of Sterculia foetida seedlings irrigated with saline water in environments with full sun, and $50 \%$ shading at 56 days after application of the treatments. Fortaleza CE, Brazil, 2012.
(2010), in which plants with reductions of $0 \%$ to $20 \%$ are tolerant, $20 \%$ to $40 \%$ are moderately tolerant; $40 \%$ to $60 \%$ are moderately sensitive, and greater than $60 \%$ are sensitive. However, the reductions were 33, 29, and 32\% for SDW, RDW and TDW, respectively, when the irrigation water had electrical conductivity of $3.2 \mathrm{dS} \mathrm{m}^{-1}(\mathrm{~S} 3)$. Therefore, the seedlings were moderately tolerant to salinity of up to $3.2 \mathrm{dS} \mathrm{m}^{-1}$, and the use of water at these salinity levels can be an alternative for seedling irrigation, with relative gain of dry matter of more than $60 \%$.

Regarding the seedling quality variables, the interaction $\mathrm{L} \times \mathrm{S}$ was significant for the $\mathrm{PH}$ to SBD ratio. Individually, the factors affected the $\mathrm{PH}$ to SDW ratio and the DQI. However, the SDW to RDW ratio had no response to the $\mathrm{L}$ and $\mathrm{S}$. The plants in $\mathrm{L} 2$ presented higher quality indexes for the $\mathrm{PH}$ to SDW ratio and the DQI, and higher mean of SDW to RDW ratio (Table 2 ).

The interaction $\mathrm{L} x \mathrm{~S}$ was significant for the $\mathrm{PH}$ to SBD ratio (Figure $3 \mathrm{~A}$ ). The salinity had no effect on the hazel sterculia seedlings in L1, however, the plants in L2 were negatively affected by the salinity levels.

The $\mathrm{PH}$ to SDW ratio increased with increasing salinity levels (Figure 3B), and the DQI reduced with increasing salinity levels (Figure 3D). The average SDW to RDW ratio was 1.91 .

The DQI was more sensitive to salinity than the other quality variables, with a relative decrease of $71 \%$ from S5 to S1, according to the regression equation.

Table 2. Analysis of variance for the effect of light availability (L) and irrigation water salinity level (S) on the quality of Sterculia foetida L. seedlings at 56 days after application of the treatments.

\begin{tabular}{|c|c|c|c|c|c|}
\hline \multirow{2}{*}{ Source of variation } & \multirow{2}{*}{ DF } & \multicolumn{4}{|c|}{ Mean square } \\
\hline & & PH/SBD & PH/SDW & SDW/RDW & DQI \\
\hline $\mathrm{L}$ & 1 & $0.58^{\star}$ & $39.90^{* *}$ & $0.50^{\text {ns }}$ & $6.22^{*}$ \\
\hline Residue (a) & 4 & 0.04 & 1.34 & 0.20 & 0.43 \\
\hline S & 4 & $0.02^{\mathrm{ns}}$ & $13.00^{*}$ & $0.16^{\mathrm{ns}}$ & $4.64^{\star *}$ \\
\hline $\mathrm{LxS}$ & 4 & $0.17^{\star *}$ & $7.21^{\mathrm{ns}}$ & $0.33^{\text {ns }}$ & $1.05^{\mathrm{ns}}$ \\
\hline Residue (b) & 16 & 0.02 & 2.94 & 0.19 & 0.45 \\
\hline $\mathrm{CV}_{\mathrm{a}}(\%)$ & & 10.44 & 27.81 & 23.60 & 34.94 \\
\hline \multirow[t]{2}{*}{$\mathrm{CV}_{\mathrm{b}}(\%)$} & & 7.59 & 41.26 & 23.24 & 35.57 \\
\hline & & \multicolumn{4}{|c|}{ Means } \\
\hline Full sun (L1) & & - & $3.00 \mathrm{~b}$ & 1.78 & $1.43 \mathrm{~b}$ \\
\hline $50 \%$ shading (L2) & & - & $5.31 \mathrm{a}$ & 2.04 & $2.34 \mathrm{a}$ \\
\hline
\end{tabular}


(A)

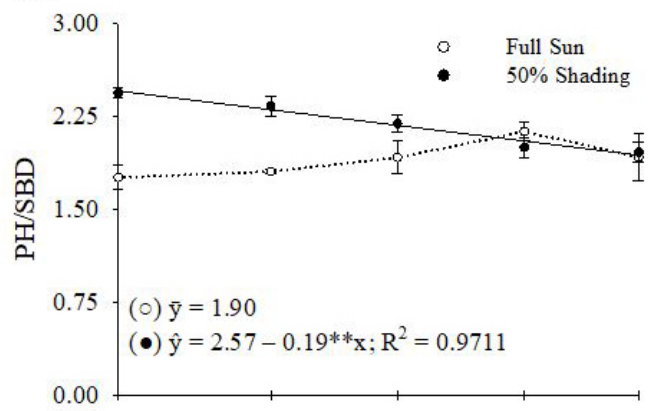

(C)

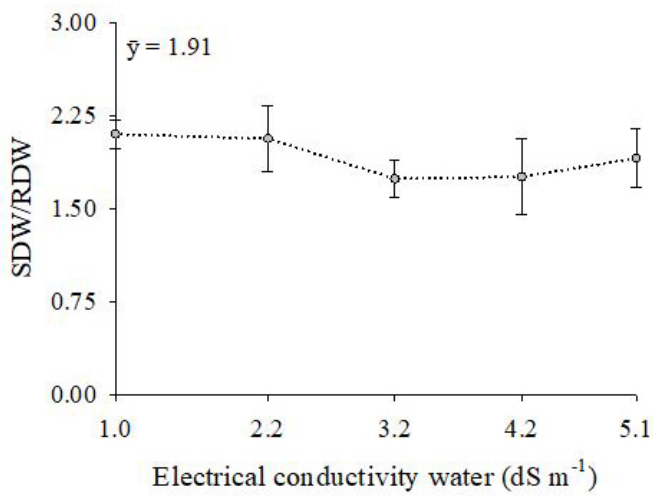

(B)

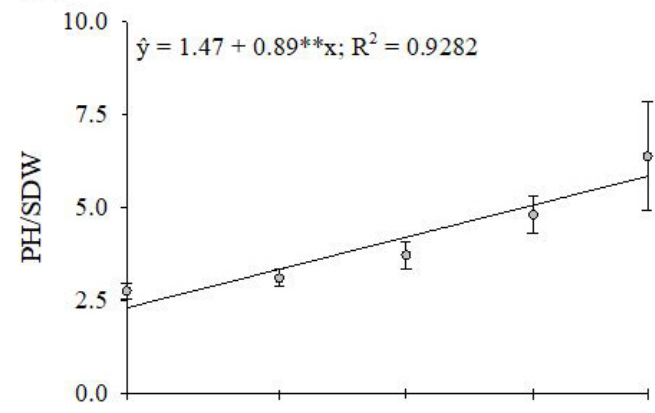

(D)

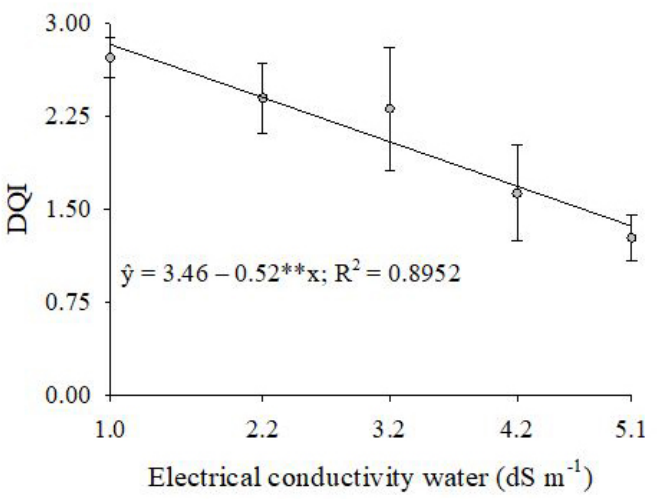

Vertical bars indicate the standard error.

Figure 3. Effect of the interaction between light availability and irrigation water salinity level on the plant height to stem base diameter ratio (PH/SBD) (A), and salinity effect on the shoot dry weight to root dry weight ratio (SDW/RDW) (B), plant height to shoot dry weight ratio (PH/SDW) (C) and Dickson quality index (DQI) (D) of Sterculia foetida seedlings at 56 days after application of the treatments. Fortaleza CE, Brazil, 2012.

The $\mathrm{PH}$ to SBD ratio expresses the balance of the seedling development in the nursery. The $\mathrm{PH}$ to SBD ratio of the seedlings did not vary significantly in L1 with increasing salinity, but showed a linear reduction in L2, with ratios of 2.94 (S1) to 1.96 (S5) at 56 DAT (Figure 3A). According to Carneiro (1995), this ratio should be between 5.4 and 8.1. This shows that the greater the stress due to irrigation with saline water the lower the seedling vigor and survival in the field.

The $\mathrm{PH}$ to SDW ratio increased with increasing $\mathrm{EC}$ in the irrigation water (Figure $3 \mathrm{~B}$ ). According to Gomes et al. (2002), the lower the PH to SDW ratio the greater the seedling vigor and survival in the field.

According to Bernardino et al. (2005), the PH to SDW ratio is not widely used to evaluate seedling quality but indicates the seedling survival potential in the field; and the increase in water salinity in both environments (full sun and shaded) can reduce the seedling survival potential, with a greater impact on seedlings in full sun environments.
The increase in salinity in L2 had no significant effect on the SDW to RDW ratio, which presented an average of 1.91 (Figure 3C). According to Dutra et al. (2012b), this result indicates an even distribution of the dry matter in the two seedling populations. Similarly, Fonseca et al. (2002) evaluated the effect of the shading period on Trema micrantha seedlings and observed the adjustment of the species to low light incidence.

The highest DQI were found in seedlings in L2 (Figure 3D). Similar results were found by Azevedo et al. (2010) in seedlings of Simarouba amara under nursery conditions, with the shading affecting the DQI. The DQI was greater under conditions of 30 and $50 \%$ shading, with greater balance of the seedlings in 50\% shading. According to Gomes et al. (2002) and Bernardino et al. (2005), the higher the DQI the better the seedling quality and their probability of survival in the field.

According to the means of all variables evaluated, the environment with $50 \%$ reduction in light availability 
was more suitable to produce hazel sterculia seedlings, even under high salinity conditions $\left(5.1 \mathrm{dS} \mathrm{m}^{-1}\right)$, when compared to the environment with full sun conditions. Seedlings under $50 \%$ shade achieved greater growth, higher biomass, and higher quality indexes, therefore presenting greater probability of survival in the field.

\section{CONCLUSION}

Light availability conditions and the irrigation water salinity level evaluated affected most of the growth and quality variables of hazel sterculia seedlings. The means of the growth and quality variables of seedlings in the environment with $50 \%$ shading were higher when compared to the seedlings in the environment with full sun.

Increasing salinity negatively affected the growth of the seedlings and most of their quality indexes. The seedlings in the environment with 50\% shading had the best quality indexes and, therefore, had greater potential for development and survival in field conditions.

\section{ACKNOWLEDGEMENTS}

The authors thank the National Institute of Science and Technology in Salinity - INCTSal for the financial support to the development of this research; To the Nucleus of Education and Research in Urban Agriculture - NEPAU, for the space granted to carry out this research and to the National Council for Scientific and Technological Development - CNPq for granting the first author's scholarship.

\section{SUBMISSION STATUS}

Received: 16 oct., 2017

Accepted: 16 nov., 2017

\section{CORRESPONDENCE TO}

\section{Breno Leonan de Carvalho Lima}

Programa de Pós-graduação em Engenharia Agrícola, Departamento de Engenharia Agrícola, Universidade Federal Rural de Pernambuco UFRPE, Dom Manoel de Medeiros, $\mathrm{s} / \mathrm{n}$, Dois Irmãos, CEP 52171-900, Recife, PE, Brasil e-mail: breno.lclima@bol.com.br

\section{FINANCIAL SUPPORT}

The resources for the execution of this research came from INCTSal (financial) and NEPAU (infrastructure).

\section{REFERENCES}

Azevedo IMG, Alencar RM, Barbosa AP, Almeida NO. Estudo do crescimento e qualidade de mudas de marupá (Simarouba amara Aubl.) em viveiro. Acta Amazonica 2010; 40(1): 157-164. http://dx.doi.org/10.1590/S004459672010000100020

Bernardino DCS, Paiva HN, Neves JCL, Gomes JM, Marques VB. Crescimento e qualidade de mudas de Anadenanthera macrocarpa (Benth.) Brenan em resposta à saturação por bases do substrato. Revista Árvore 2005; 29(6): 863-870. http://dx.doi.org/10.1590/S0100-67622005000600004.

Câmara CA, Endres L. Desenvolvimento de mudas de duas espécies arbóreas: Mimosa caesalpiniifolia Benth. e Sterculia foetida L. sob diferentes níveis de sombreamento em viveiro. Floresta 2008; 38(1): 43-51. http://dx.doi. org/10.5380/rf.v38i1.11026.

Carneiro JGA. Produção e controle de qualidade de mudas florestais. Campos dos Goytacazes: UENF; 1995.

Cavalcante ALG, Oliveira FA, Pereira KTO, Dantas RP, Oliveira MKT, Cunha RC et al. Desenvolvimento de mudas de mulungu fertirrigadas com diferentes soluções nutritivas. Revista Floresta 2016; 46(1): 47-55. http:// dx.doi.org/10.5380/rf.v46i1.34888.

Dias-Filho MB. Physiological response of Solanum crinitum Lam. to contrasting light environments. Pesquisa Agropecuária Brasileira 1997; 32(8): 789-796.

Dickson A, Leaf AL, Hosner JF. Quality appraisal of white spruce and white pine seedling stock in nurseries. Forestry Chronicle 1960; 36(1): 10-13. http://dx.doi.org/10.5558/ tfc36010-1.

Dutra TR, Massad MD, Sarmento MFQ, Oliveira JC. Emergência e crescimento inicial da canafístula em diferentes substratos e métodos de superação de dormência. Revista Caatinga 2012a; 25(2): 65-71.

Dutra TR, Grazziotti PH, Santana RC, Massad MD. Desenvolvimento inicial de mudas de copaíba sob diferentes níveis de sombreamento e substratos. Revista Ciência Agronômica 2012b; 43(2): 321-329. http://dx.doi. org/10.1590/S1806-66902012000200015.

Dutra TR, Grazziotti PH, Santana RC, Massad MD. Qualidade de mudas de copaíba produzidas em diferentes substratos e níveis de sombreamento. Revista Floresta 2015; 45(3): 635-644. http://dx.doi.org/10.5380/rf.v45i3.35686.

Dutta S, Hossain MK, Das S. Silviculture-genetics research in Bangladesh: a review. International Journal of Forest Usufructs Management 2016; 17(1): 79-98. 
Empresa Brasileira de Pesquisa Agropecuária - EMBRAPA. Sistema Brasileiro de Classificação de Solos. 3. ed. Brasília: Embrapa; 2013.

Fageria NK, Soares Filho W, Gheyi HR. Melhoramento genético vegetal e seleção de cultivares tolerantes à salinidade. In: Gheyi HR, Dias NS, Lacerda CF, editores. Manejo da salinidade na agricultura: estudos básicos e aplicados. Fortaleza: INCTSal; 2010.

Feikema PM, Baker TG. Effect of soil salinity on growth of irrigated plantation Eucalyptus in south-eastern Australia. Agricultural Water Management 2011; 98(7): 1180-1188. http://dx.doi.org/10.1016/j.agwat.2011.03.005.

Felfili JM, Hilgbert LF, Franco AC, Sousa-Silva JC, Resende AV, Nogueira MVP. Comportamento de plântulas de Sclerolobium paniculatum Vog. Var. rubiginosum (Tul.) Benth. sob diferentes níveis de sombreamento em viveiro. Revista Brasileira de Botanica 1999; 22(2): 297-301.

Ferreira DF. Sisvar: a computer statistical analysis system. Ciência e Agrotecnologia 2011; 35(6): 1039-1042. http:// dx.doi.org/10.1590/S1413-70542011000600001.

Fonseca EP, Váleri SV, Miglioranza E, Fonseca NAN, Couto L. Padrão de qualidade de mudas de Trema micrantha (L.) Blume, produzidas sob diferentes períodos de sombreamento. Revista Árvore 2002; 26(4): 515-523. http://dx.doi.org/10.1590/S0100-67622002000400015.

Freire ALO, Sousa Filho GM, Miranda JRP, Souto PC, Araújo LVC. Crescimento e nutrição mineral de nim (Azadirachta indica A. Juss.) e cinamomo (Melia azedarach Linn.) submetidos à salinidade. Ciência Florestal 2010; 20(2): 207-215. http://dx.doi.org/10.5902/198050981845.

Gomes JM, Couto L, Leite HG, Xavier A, Garcia SLR. Parâmetros morfológicos na avaliação da qualidade de mudas de Eucalyptus grandis. Revista Árvore 2002; 26(6): 655-664. http://dx.doi.org/10.1590/S0100-67622002000600002.
Gonçalves JLM. Recomendações de adubação para Eucalyptus, Pinus e espécies típicas da Mata Atlântica. Piracicaba: Esalq; 1995.

Holanda AC, Santos RV, Souto JS, Alves AR. Desenvolvimento inicial de espécies arbóreas em ambientes degradados por sais. Revista de Biologia e Ciências da Terra 2007; 7(1): 39-50.

Lima JD, Silva BMS, Moraes WS, Dantas VAV, Almeida CC. Efeitos da luminosidade no crescimento de mudas de Caesalpinia ferrea Mart. ex Tul. (Leguminosae, Caesalpinoideae). Acta Amazonica 2008;38(1): 5-10.

Lorenzi H. Árvores brasileiras: manual de identificação e cultivo de plantas arbóreas nativas do Brasil. Nova Odessa: Plantarum; 1998.

Mendonça AVR, Carneiro JGA, Barroso DG, Santiago AR, Rodrigues LA, Freitas TAS. Características biométricas de mudas de Eucalyptus sp. sob estresse salino. Revista Árvore 2007; 31(3): 365-372. http://dx.doi.org/10.1590/ S0100-67622007000300001.

Pinto JRS, Dombroski JLD, Freitas RMO, Souza GO, Santos JH Jr. Crescimento e índices fisiológicos de Tabebuia aurea, sob sombreamento no semiárido. Revista Floresta 2016; 46(4): 465-472.

Rhoades J, Kandiah A, Mashali AM. Uso de águas salinas na produção agrícola. Gheyi HR, Souza JR, Queiroz JE, tradutores. Campina Grande: UFPB; 2000.

Silva KB, Mata MF, Alcântara Bruno RL. Tratamentos pré-germinativos para superação da dormência de sementes de Sterculia striata A. St. Hil. Naldin. Semina 2012; 33(3): 857-866. 